\title{
Levels of ICT Integration among Teacher Educators in a Teacher Education Academic College
}

\author{
Orit Avidov-Ungar \\ The Open University, \\ Achva Academic College, \\ Israel \\ oritav@openu.ac.il
}

\author{
Irit Emma Iluz \\ Barry School, \\ Achva Academic College, \\ Israel \\ emairit@gmail.com
}

\begin{abstract}
This article examines the perspective of teacher educators and academic officials in an academic teacher education program regarding the integration of ICT in the teacher education program. The study portrays the current state of the ICT integration process and the implementation of the program for "Adapting Teacher Training Colleges to 21st Century Education" in a specific academic college in one of Israel's outlying areas. This mixed methods study combined quantitative and qualitative methods. Data was collected by means of a closed questionnaire, an open-ended questionnaire for the teacher educators $(\mathrm{N}=68)$, and semi-structured interviews conducted with the academic officials $(\mathrm{N}=12)$. Findings revealed a hierarchical range of ICT integration in teaching, which reflects different profiles of teacher educators who integrate innovative pedagogies. The three integration levels (the basic level, the focused level, and the creative level) reflect the scope of ICT integration in the context of teacher training creating a continuum of integration and implementation, which can serve as an infrastructure for the effective adoption and integration of this innovative pedagogy by teacher educators and academic officials in academic teacher training colleges.
\end{abstract}

Keywords: teacher training, teacher educators, ICT integration, innovative pedagogy.

\section{Introduction}

The 21st century poses new challenges and requirements to the education system in general, and to the teacher training system in particular. As a result many countries, among them Israel, invest

Material published as part of this publication, either on-line or in print, is copyrighted by the Informing Science Institute. Permission to make digital or paper copy of part or all of these works for personal or classroom use is granted without fee provided that the copies are not made or distributed for profit or commercial advantage AND that copies 1) bear this notice in full and 2) give the full citation on the first page. It is permissible to abstract these works so long as credit is given. To copy in all other cases or to republish or to post on a server or to redistribute to lists requires specific permission and payment of a fee. Contact Publisher@InformingScience.org to request redistribution permission. a great deal of resources and effort to upgrade their education systems in order to meet the demands of the era of information and globalization (ASTC, 2010; Barell et al., 2010; Mishra \& Kereluik, 2011, p. 21). The investment in teacher training helps improve teaching and constitutes a way to leverage the achievements of students in preparation for their future (McKinsey Report, 2007). 21st-century skills require a shift

\section{Editor: Janice Whatley}

An earlier, shorter version of this paper was presented at the Chais conference 2014, in Raanana, Israel, and included in Y. Eshet-Alkalai, A. Caspi, N. Geri, Y. Kalman, V. Silber-Varod, \& Y. Yair (Eds.), Proceedings of the Chais Conference for the Study of Innovation and Learning Technologies 2014: Learning in the Technological Era. Raanana: The Open University of Israel. 
in teachers' roles (Postholm, 2006), a shift in understanding the learning process, and a transition from traditional-style teaching to teaching using a social-constructivist approach (Bransford, Brown, \& Cocking, 2000; Salomon, 1992). Thus, many studies focus on the need to adapt schools to the 21 st century and the need for an essential change in the image and role of the teacher (e.g., Bransford et al., 2000; Barak, Ben-Chaim \& Zoller, 2007). The goal of the Israeli program "Adapting Teacher Training Colleges to 21st Century Education" is to prepare teacher trainees who are intending to teach in the education system for the anticipated change by training them to make intelligent use of ICT technology, improve and vary traditional teaching methods, and develop innovative pedagogy that will lead to their successful and effective integration as teachers in schools (Ministry of Education, 2011). Thus, teacher educators' capacity to embrace the upcoming changes as part of the implementation of the national program is an essential condition for their ability to experience real-time situations that require planning, structuring, and implementation of innovative pedagogy for teaching (ASTC, 2010; Barell et al., 2010; Mishra \& Kereluik, 2011; Partnership for 21st Century Skills, 2009).

The current study is derived from a broader study conducted as part of an intercollegiate collaboration, which included eight academic teacher training colleges in Israel, and examined the implementation of the national program for Adapting Teacher Training Colleges to 21st Century Education (Goldstein et al., 2012). The study presented in this article constitutes a case study within the larger collaborative and focuses on a single teacher training college located in the southern periphery of the State of Israel. The current study was designed to characterize the process of ICT integration and the implementation of this innovative pedagogy in a teacher training college, while taking into account the manner and degree of ICT use for pedagogical purposes by the teacher educators. This is an important study because it focuses on the population of teacher educators, which has an enormous and direct influence on future teachers' ability to develop and formulate innovative educational perceptions (Gronseth et al., 2010). Teacher training institutes throughout the world, as well as in Israel, have developed models for implementing ICT in the process of training technologically adept teachers (Bullock, 2004; Collier, Weinburgh, \& Rivera, 2004; Dawson, 2006; Granston, 2004; Kay, 2006). The contribution of the current study is in taking an in-depth view of a single teacher training college, from which it may be possible to learn about the process in other colleges, identify aspects which influence ICT integration, and indicate characteristics that contribute to the effective integration of innovative pedagogy among teacher educators in teacher training colleges. In addition, the study highlights the factors that impede and those which encourage integration of innovative pedagogy, which can serve as a means for advancing teacher training processes, leading to the adoption of innovations by regarding them as a challenge, rather than as a threat, in this era of shifts and changes (Bransford, Darling-Hammond, \& LaPage, 2005).

\section{Educating Teachers in an Era of Change}

The teacher training system is currently coping with a wave of educational reforms, which aim to help the system adapt to the spirit of the times and to the standards expected of graduates of a teacher training program (Darling-Hammond, 2000; Fullan 2001). Over the years, various approaches to teacher training have been developed throughout the world, from which a variety of models and training programs, featuring unique characteristics, have been derived (Black \& Smith, 2009; OECD, 2010). Processes of change and the evolution of so many approaches to teacher training have been accompanied by a lack of satisfaction and an unclear and vague picture of the future of teacher training (Beaudin \& Hadden, 2005). The desire for graduates to be prepared and skilled and to be capable of meeting international standards in the era of information technology has motivated many countries around the world to attribute a great deal of importance to this issue (ISTE, 2008), leading to the updating of teacher training systems and their adjustment to the requirements of the 21 st century (Birch \& Sankey, 2008). The urgency to create 
change in the teacher training system has been felt in the State of Israel too. Only a few teachers integrate into their teaching methods models that meet the progressive requirements for adapting teaching to the skills and needs of students of the 21st century (OECD, 2010). Thus, the changes in the form of teacher education in teacher training colleges convey a profile of the shifts and ongoing changes that have taken place in teacher training programs, in efforts to integrate ICT, in the perceived role of the teacher and in the essence of the teaching profession (Back, 2012).

\section{Teacher Educators Integrate Innovative Pedagogy}

Many studies have focused on issues related to the integration of ICT and the assimilation of innovative pedagogy by teachers and academic faculty in schools (e.g., Hall \& Hord, 1987; Sandholtz, Ringstaff, \& Dwyer, 1997; Siemens \& Tittenberger, 2009). However, very few studies have focused on teacher educators and teacher training institutions which prepare future teachers to enter the profession. A great number of teacher educators have integrated ICT into their teaching, yet for many this has not led to changes in their teaching methodologies (Bransford et al., 2000). Teacher educators in teacher training colleges often delay adopting technological innovations in teaching because of a lack of appropriate software and materials and a lack of hardware (Goktas, Yildirim, \& Yildirim, 2009). Studies report a variety of obstacles and difficulties encountered by academic teaching faculty related to their pedagogical beliefs and perceptions, management of time and resources, and a supportive technical and pedagogical framework (Brzycki \& Dudt, 2005; Goktas et al., 2009; Gomez, Sherin, Griesdorn, \& Finn, 2008; Maltz \& DeBlois, 2005; Moser, 2007).

Teacher training is a necessary precondition for assimilating the conceptual changes related to teaching and for integrating ICT in schools (Kay, 2006). A significant educational change can take place only following a transformation in the beliefs and perceptions of teacher educators, since their influence on future teachers is crucial. It is up to teacher educators to lead and implement change by adopting pedagogical innovation and applying it (Cochran-Smith, 2005; Fullan, 2001; Swennen \& van der Klink, 2009). Successful assimilation demands a positive attitude of the parties involved towards the use of innovative technology (Harris \& Hofer, 2009). A positive attitude is based on an understanding that the technology is beneficial, in that it helps attain optimal performance in the teaching and learning processes; similarly, positive attitudes regarding ICT and acknowledgment of its advantages constitute a means for creating the chance to use ICT in teaching processes (F. Davis, Bagozzi \& Warshaw, 1989; Kay, 2006). In Israel, as in other parts of the world, teacher educators will be able to face the upcoming changes introduced through the national program for "Adapting Teacher Training Colleges to 21st Century Education" if they themselves undergo a process of learning, which would lead them to effectively integrate ICT and to redesign and restructure their perceptions and beliefs regarding ICT implementation in teaching (Postholm, 2006; Surry, Ensminger, \& Jones, 2003).

There has been a paradigm shift in the way teaching is perceived, namely, there has been a transition to a constructivist approach of adopting a learner-centered approach to teaching (Barak, BenChaim, \& Zoller, 2007). Teachers who implement a learner-centered process for learning and teaching are able to effectively assimilate and integrate technology in their teaching (Ertmer \& Ottenbreit-Leftwich, 2010). Thus, teachers are expected to develop learning environments that generate relevant tasks, challenges, and content (National Research Council [NRC], 1996), while they simultaneously take an active role in the learning community (Barak, Carson, \& Zoller, 2007). Many studies have demonstrated that despite the awareness of teacher educators of the potential pedagogical benefits of integrating ICT in teaching, a substantial portion of this population still integrates ICT in a traditional fashion with lectures and exercises, without introducing any fundamental change in the patterns of teaching and learning (Bransford et al., 2000). Other studies on teacher educators who integrate ICT in teacher training have indicated that they are 
uninformed about ways to effectively integrate ICT tools in their lessons (Surry et al., 2003). These facts suggest that innovative strategies must be developed and implemented in the teacher training process. Thus, the population of teacher educators in teacher training colleges becomes a driving factor in leading the upcoming change, as they incorporate the innovative pedagogy among novice teachers to practice their profession in the 21st century (Black \& Smith, 2009; Valdez, Fulton, Glenn, Wimmer, \& Blomeyer, 2004).

The term "innovative pedagogy" describes a pedagogical structure in which the curriculum is adapted to changes in the social, cultural, and economic contexts (Sharples et al., 2013). In this process of pedagogical change, the technological-content knowledge varies according to the everchanging environment; however, "innovative pedagogy" defines not only the content that is learned, but also the educational value of adapting the students' skills to the 21 st century (Fullan, 2013).

In the light of this situation, the aim of the current study is to describe both the factors that influence teacher educators to integrate ICT in teacher training processes, as well as the manner in which they implement the innovative pedagogy in teaching and learning processes. The resulting description will pay particular attention to the ways and degree to which they use ICT tools for pedagogical purposes. Hence, the goals of this current study are to identify the characteristics of ICT implementation in a teacher training program. Also, it evaluates the teacher educators' pedagogical and technological skills and ways in which they use ICT for pedagogical purposes. To this end, the following research goals have been defined:

(1) To identify the skills and the attitudes of teacher educators and academic officials in the teacher training college to the integration of ICT in teaching.

(2) To examine the levels of ICT integration in innovative pedagogy among teacher educators and academic officials in the teacher training college.

\section{Methodology}

\section{The Study Population}

This study population included 68 teacher educators in a teacher training college $(\mathrm{N}=68)$, who constitute $60 \%$ of all of the teacher educators in the college. Of these 68 participants, $77 \%$ were women, and $23 \%$ were men. Of the teacher educators in the college, $40 \%$ are positioned as lecturers. As for their seniority, 30\% have 1-5 years of experience, $40 \%$ have $6-14$ years, and $30 \%$ of them have over 15 years of experience. For $50 \%$ of the teacher educators, their work in the college is their major job (more than $75 \%$ of their total working hours).

The teacher educators are affiliated with various teaching tracks (Table 1).

At first, 48 teachers responded using a printed version of the questionnaire. To increase the sample size, we created an online version of the questionnaire, to which 20 more teachers responded (a total of 68 teachers which constitutes $60 \%$ of the college staff). All questionnaires were anonymous to secure the participants' privacy.

In addition, 12 of the participating teachers held a position as an academic official in the college; among them were the president of the college, the college CEO, the vice president for academic affairs, the head of the research authority, the head of the ICT learning and teaching unit, the head of the college's school of education, the head of the graduate school, the coordinator of ICT and learning, the didactic coordinator of the ICT unit, the manager of the active learning classroom, and the coordinator of trainee advisors.

Table 1: The Sample of Teacher Educators in the College According to Teaching Tracks 


\begin{tabular}{|l|l|}
\hline $\begin{array}{l}\text { Teacher Educators' Teaching } \\
\text { Tracks }\end{array}$ & Percentage of Teachers \\
\hline Early Childhood Education & $24 \%$ \\
\hline Elementary School Education & $47 \%$ \\
\hline $\begin{array}{l}\text { Middle School and High School Edu- } \\
\text { cation }\end{array}$ & $35 \%$ \\
\hline Special Education & $19 \%$ \\
\hline Masters in Education & $6 \%$ \\
\hline $\begin{array}{l}\text { Professional Development and Career } \\
\text { Change for Academics }\end{array}$ & $4 \%$ \\
\hline
\end{tabular}

\section{Research Methods}

The current research was based on a mixed methods approach, whereby the qualitative component was based on grounded theory (Strauss \& Corbin, 1990). Data was collected throughout the academic year 2012-2013. Interviews were analyzed using the Atlas. ti 7.0 software program. Conducting data analysis using the grounded theory approach made it possible to construct and formulate a theory that emerged from the field and from the participants' environment. The data analysis consisted of several stages:

(1) Primary encoding - identifying and defining primary categories, which is the first stage of theoretical sampling.

(2) Designing categories - defining the criteria for the categories, while constantly honing the category definitions and continuing the theoretical sampling process.

(3) Clarifying the criteria; designing and finalizing the system of categories.

(4) Outlining the hierarchies among the categories and identifying core categories, which constitute the nucleus of the analysis. At this stage, relationships emerged among the various categories, as well as between core and non-core categories.

(5) Creating a theoretical structure based on the previous stages, using the categories identified.

All of the stages were validated separately by each researcher. In stages (2) and (4), three external experts from the intercollegiate team assisted in the validation.

Use of the Atlas. ti 7.0 software program made it possible to create a semantic map in the form of a diagram, reflecting the reciprocal relationships, the aggregation (the creation of metacategories), and segregation (the creation of subcategories). The map was useful for conceptualizing the main issue under study, which in turn made it possible for the researchers to control the large amount of verbal data.

The quantitative data collected from the questionnaires were analyzed using the SPSS software program (Version 16). The various segments of the questionnaire were tested for reliability; inferential statistical analyses were also conducted, including ANOVA for finding the differences between the groups.

\section{Research Tools}

Three research tools were used, which had been developed earlier by the intercollegiate research team. The intercollegiate collaborative research team network, "ICT in Teacher Education Col- 
leges", was funded by the Ministry of Education and the MOFET Institute. The following tools were employed:

(1) A questionnaire for teacher educators regarding the national program for the Integration of ICT in Teacher Education Colleges. This questionnaire examined the perceptions and attitudes of the teacher educators regarding the integration of ICT in the process of teaching, as well as the manner and degree to which they used ICT in teaching $(\mathrm{N}=68)$. The questionnaire included five sections. In the current study, only three sections of the questionnaire sections were used, namely, those related to the current study's research questions. The questionnaire examined knowledge of teaching integrating ICT and teacher educators' use of ICT and had a section examining attitudes towards the use of ICT. The average time to complete the questionnaire was 20 minutes. Internal consistency of the questionnaire sections was measured using Cronbach's alpha. Findings of internal reliability of the research tools are presented in Table 2 , showing that the three measurements we used - the attitudes towards ICT use and TPACK knowledge (Mishra \& Koehler, 2006), attitudes toward ICT use, and the use of ICT tools for personal or professional needs have high internal consistency. In the questionnaire, we used a five-point Likert scale. In the Findings part of the paper, we present all questions in the questionnaire.

Table 2: Study Questionnaire and Reliability Levels

\begin{tabular}{|c|l|l|}
\hline Cronbach's alpha & $\begin{array}{l}\text { Sample Questions and } \\
\text { Statements }\end{array}$ & Topic \\
\hline $\mathbf{9 1}$ & $\begin{array}{l}\text { Example from the 5 ques- } \\
\text { tions in this section: I can } \\
\text { choose to use a technology } \\
\text { in the classroom that suits } \\
\text { my teaching approach }\end{array}$ & $\begin{array}{l}\text { Assessment of Technological } \\
\text { Pedagogical Content } \\
\text { Knowledge (TPACK) } \\
\text { Based on: Mishra \& Koehler, } \\
\text { 2006) }\end{array}$ \\
\hline $\mathbf{8 2}$ & $\begin{array}{l}\text { Example from the 6 ques- } \\
\text { tions in this section: Using } \\
\text { ICT could improve my } \\
\text { teaching }\end{array}$ & Attitudes toward ICT use \\
\hline $\mathbf{8 3 2}$ & $\begin{array}{l}\text { Example from the 12 ques- } \\
\text { tions in this section: I use } \\
\text { social networks for person- } \\
\text { al and professional purpos- } \\
\text { es }\end{array}$ & $\begin{array}{l}\text { Use of ICT tools for personal } \\
\text { or professional needs }\end{array}$ \\
\hline
\end{tabular}

(2) Open-ended Attitude Questionnaire. This questionnaire included three open-ended questions, in which teacher educators were asked to freely address aspects related to the factors that deter and those that encourage ICT integration in the college and to describe what, in their opinion, would indicate successful and effective ICT integration in the college $(\mathrm{N}=68)$.

(3) Semi-structured Interview. The interview examined the perspectives of academic officials in the college regarding the integration of ICT in teaching $(\mathrm{N}=12)$. The interview included 26 questions related to the personal attitudes of interviewees regarding ICT integration in the teaching process in the college and asked them to describe the process of ICT integration in the college, taking into account the college's vision as related to ICT, as well as the manner in which teacher educators integrated ICT in their teaching practices. The questions addressed both personal and organizational aspects (for the full version of the interview see the Appendix). Interviews were conducted by both of the researchers; each interview lasted approximately 1 hour and 15 minutes. 
Transcription took place immediately after the interview was concluded to prepare the data for input to the analysis software.

\section{Findings}

The findings are presented here as they emerged from the analysis of the data, which were collected using the quantitative and qualitative tools. The order of presentation corresponds to the two research questions.

\section{(1) The Skills and the Attitudes of Teacher Educators and of Academic Officials in the Teacher Training College Regarding the Integration of ICT in Teaching}

Analysis revealed that factors that influence ICT integration in teaching and constitute the infrastructure for the perceptions of teacher educators and academic officials in the teacher education college can be divided into skills and attitudes. Skills refer to Teacher Educators' Technological Pedagogical Content Knowledge (TPACK). Attitudes are divided into personal factors and organizational factors.

The personal skills of Teacher Educators' Technological Pedagogical Content Knowledge (TPACK) and the attitudes including organizational factors and personal factors of the teacher educators and academic officials that affect the process of ICT integration are described in Figure 1.

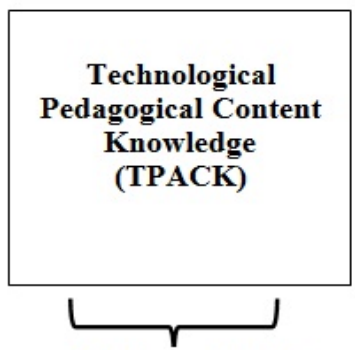

(1) Personal skills

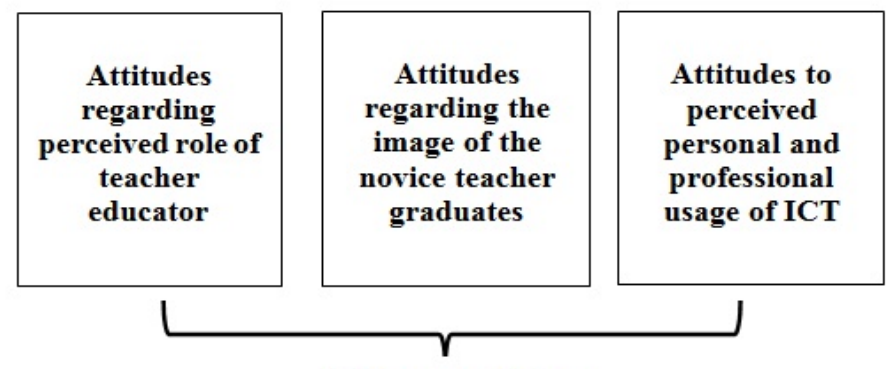

(2) Personal factors

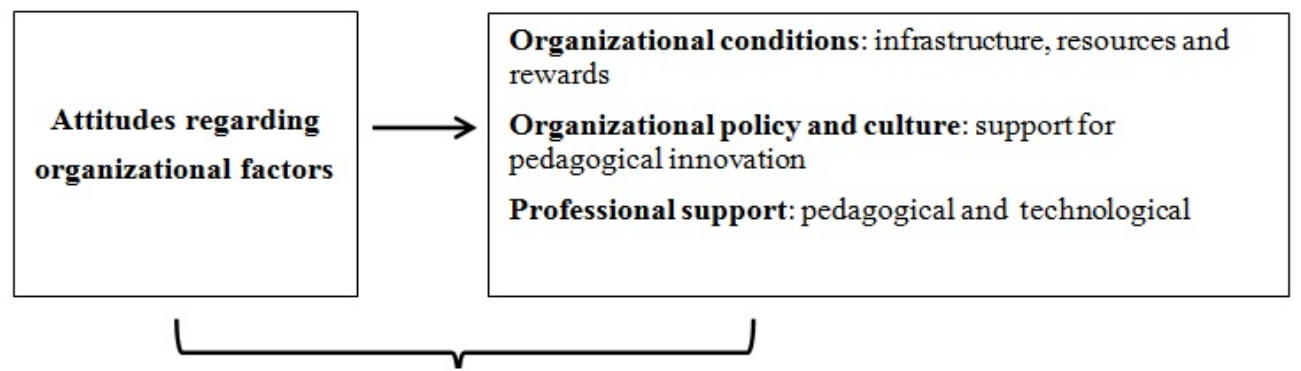

(3) Organizational factors

Figure 1: Personal skills, personal and organizational factors that influence ICT integration among teacher educators and academic officials in the teacher training college

The personal skills and the attitudes of teacher educators and of academic officials in the teacher training college regarding the integration of ICT in teaching is presented in Figure 1 including skills and attitude of the teacher educators and academic officials. Below is a description of (1) the personal skills, (2) the personal factors and (3) the organizational factors. 


\section{Personal skills regarding Technological Pedagogical Content Knowledge (TPACK)}

The significant factor that affects ICT integration in the teacher training college is teacher educators' personal skills in terms of technological-pedagogical knowledge (TPACK) and their ability to combine the three fields of knowledge in an informed and intelligent manner. Table 3 presents the means and standard deviations from responses to the questions regarding the level of technological-pedagogical knowledge of the teacher educators.

Table 3: Teacher Educators' Technological Pedagogical Content Knowledge (TPACK) Skills

\begin{tabular}{|c|c|l|}
\hline SD & $\begin{array}{c}\text { Average } \\
\text { (Scale 1-5) }\end{array}$ & Assess your knowledge regarding ICT integration \\
\hline .87 & 4.19 & I spend time thinking about how best to integrate ICT in my lessons \\
\hline .94 & 4.18 & I am able to match the use of ICT to various teaching activities \\
\hline .88 & 4.15 & $\begin{array}{l}\text { I can select the use of a type of technology in class that suits my teaching } \\
\text { style }\end{array}$ \\
\hline .92 & 3.96 & $\begin{array}{l}\text { I can select the use of a type of technology in class that suits my students' } \\
\text { learning styles }\end{array}$ \\
\hline 1.01 & 3.92 & $\begin{array}{l}\text { I am able to teach classes that offer an optimal combination of knowledge, } \\
\text { pedagogy and technology }\end{array}$ \\
\hline .80 & 4.09 & \begin{tabular}{l} 
Average of all questionnaire items \\
\hline
\end{tabular} \\
\hline
\end{tabular}

As the findings presented in Table 3 indicate, teacher educators assessed their level of technological-pedagogical knowledge as relatively high, especially in the statements that describe their ability to use the technology in an informed manner and match it to their teaching activities. This finding is supported also in the qualitative statements, for example;

"Students must demonstrate control not only of the technology, but also in their ability to exercise pedagogical considerations regarding the activation of the technology-- that is the work that we do in our courses for integrating ICT in teaching a discipline." (Yoram, Teacher Educator, Elementary School Education track).

\section{Personal factors}

The quantitative analysis shows that the attitudes of teacher educators to the use of ICT are positive. Table 4 presents the means and standard deviations of findings from the subsection of the questionnaire which examined teacher educators' attitudes to the use of ICT in teaching.

Findings indicate that teacher educators have a positive attitude towards ICT and its use in their teaching $(\mathrm{M}=3.97, \mathrm{SD}=.81)$. 
Table 4: Teacher Educators' $(N=68)$ Attitudes toward the Integration of ICT: Means and Standard Deviations (SD)

\begin{tabular}{|l|l|l|}
\hline SD & Average & Attitudes toward the Integration of ICT \\
\hline .92 & 4.49 & Integrating ICT could improve my teaching \\
\hline 1.12 & 4.35 & ICT use does not fit in with my teaching style \\
\hline 1.22 & 4.24 & $\begin{array}{l}\text { ICT use does not correspond to my perceptions regarding the teacher's } \\
\text { role }\end{array}$ \\
\hline 1.12 & 4.07 & Using ICT increases collaboration between learners \\
\hline 1.55 & 3.42 & Using ICT could cause alienation between students and teacher \\
\hline $\mathbf{8 1}$ & $\mathbf{3 . 9 7}$ & Average of all questionnaire items \\
\hline
\end{tabular}

From the qualitative analysis we found that personal factors of the teacher educators and academic officials refer to:

- Teacher educators' perception of their role.

- The perceived image of the novice teachers who graduate from the college.

- Their personal and professional perceptions of ICT.

Below is a description of the three personal factors of the teacher educators and academic officials to which they refer.

Attitudes regarding perceived role of teacher educator. Based on the interviews, two major aspects relating to teacher educators' role perceptions were revealed. (a) Teacher educators see themselves as role models for the novice teachers; thus, they feel responsible for training graduates to adhere to high standards and become capable of facing the challenges posed by the $21 \mathrm{st}$ century education system. (b) Teacher educators perceive their role as autonomous, allowing them a broad range of options, based on their professional role definition. One of the interviewees expressed it thus:

"We are held responsible for training teachers who are capable of meeting the challenges awaiting them beyond the college perimeters once they have completed their studies; they must be prepared in terms of ICT." (Sharon, Elementary School Education track).

Attitudes regarding the image of the novice teacher graduates. Teacher educators and academic officials perceive the trainees who graduate as the teachers of the future, whose pupils will be very well-informed about and familiar with advanced technologies. Hence, the students at the teacher training college need a great deal of guidance, in order to develop the ability to make informed decisions regarding efficient and effective use of ICT content and pedagogy. One of the interviewees expressed it thus:

"Our students are going to become teachers who will have to cope with students who are more advanced technologically than we are; therefore, it is important to prepare them for this situation" (Anat, Middle School and High School Education track).

There is a link between the teacher educators' perception of their own role and their perception of the image of the teacher graduates; the two perceptions sustain each other, in a reciprocal relationship. 
Attitudes to perceived personal and professional usage of ICT. Analysis of the findings indicated that academic officials demonstrated an ambivalent attitude regarding the integration of ICT in teaching. On the one hand, interviewees expressed their understanding and recognition of the importance of using ICT in teaching; they consider ICT a means for improving teaching, and they recognize it as a necessity which they must accept. On the other hand, statements also indicated contrary attitudes and even reservations about the use of ICT, particularly in the context of teacher training. They considered ICT to be a medium that leads to severed communication and causes feelings of distancing between the trainees and the teacher educators who are responsible for their professional training. One of the interviewees expressed it thus:

"I am very ambivalent about the integration of ICT, because --on the one hand, there is really no choice and we must progress with the times and cannot lag behind. On the other hand, there are moments when I feel that there is too much attention directed at the topic of ICT and too many resources and funds are invested in the metal and hardware and not enough in truly training the teachers." (Devora, Early Childhood Education track).

In summary, the factors that affect ICT integration are rooted in personal factors, in the perspectives of the teacher educators and those of the academic officials, specifically, in their role perception, their perceived image of the teacher training graduates, their perceptions of ICT, and their technological and pedagogical skills.

\section{Organizational factors}

Organizational factors that affect ICT integration among teacher educators and academic officials include factors that inhibit as well as those that promote ICT integration, as shown in Figure 1.

Interview findings suggest that organizational factors can either promote, or, in cases in which the organization does not approve of ICT integration, can inhibit ICT integration among teacher educators and academic officials. The organizational factors found in the study included conditions in the organization, the organizational culture and policy, as well as professional support. Below is a description of each of the factors.

Organizational conditions. Academic officials referred to infrastructure, resources, and rewards provided by the college. Most of the academic officials expressed their satisfaction with the resources and infrastructure available. This feeling was supported by the teacher educators' reports in their questionnaires and interviews. In terms of technical support and computer availability, reports indicated maximum availability. In contrast, in terms of providing encouragement and incentives for teacher educators to implement and integrate ICT as a pedagogical tool, reports indicated low levels of availability and support. Thus, for example, one interviewee noted the following:

"Encouragement and incentives are a part that is missing; all I do is based on my own initiative, because it interests me. I think that if they found 1001 different ways to encourage teacher educators, more teachers would want to integrate and implement ICT"' (Dana, Special Education track).

Organizational policy and culture. The majority of interviewees (84\%) found that the organization provided a culture and policy to enable pedagogical innovation. They described the organization as undergoing long-term processes of change. Along with these statements, there were also those who claimed that due to organizational changes that took place in the college, the importance and urgency of ICT implementation declined. The following is an excerpt from one of the interviews: 
"Members of the managing team provide freedom and support and are very much involved, because we understand that otherwise there would be no progress." (Eva, Elementary School Education track).

Professional support. Teacher educators' professional development, knowledge of technological tools, and integration of innovative pedagogy in teaching all serve as catalysts for ICT integration. It appears that the combination of workshops, additional study days in which teacher educators were shown examples of "success stories", as well as the training that academic officials received at the Ministry of Education, all contributed to a process of professional development in ICT. Thus, for example, one interviewee noted the following:

"I went through the training session last year, and now I work with pedagogical advisors and help them with ICT integration and --it works." (Adva, Masters in Education track).

In addition to the training that took place at the Ministry of Education, there were also workshops for the pedagogical advisors. The idea was that mainly the pedagogical advisors would integrate ICT, because they are the ones who influence the students the most.

One of the more notable points raised in the interviews in relation to the professional support factor was that professional responses and ongoing as well as need-based guidance were highly accessible and available. One interviewee expressed it thus:

"A lecturer who decides to construct an online virtual course receives technological and pedagogical assistance and support from the ICT unit in the college; the team members are available at all times, and are even available to help during the lesson." (Morin, Elementary School Education track).

\section{(2) Levels of ICT Integration in Innovative Pedagogy among Teacher Educators and Academic Officials in a Teacher Training College}

Three different levels of ICT integration could be discerned from the findings: basic, focused, and creative. The outcomes obtained at each of the three levels of ICT integration are described in Figure 2.

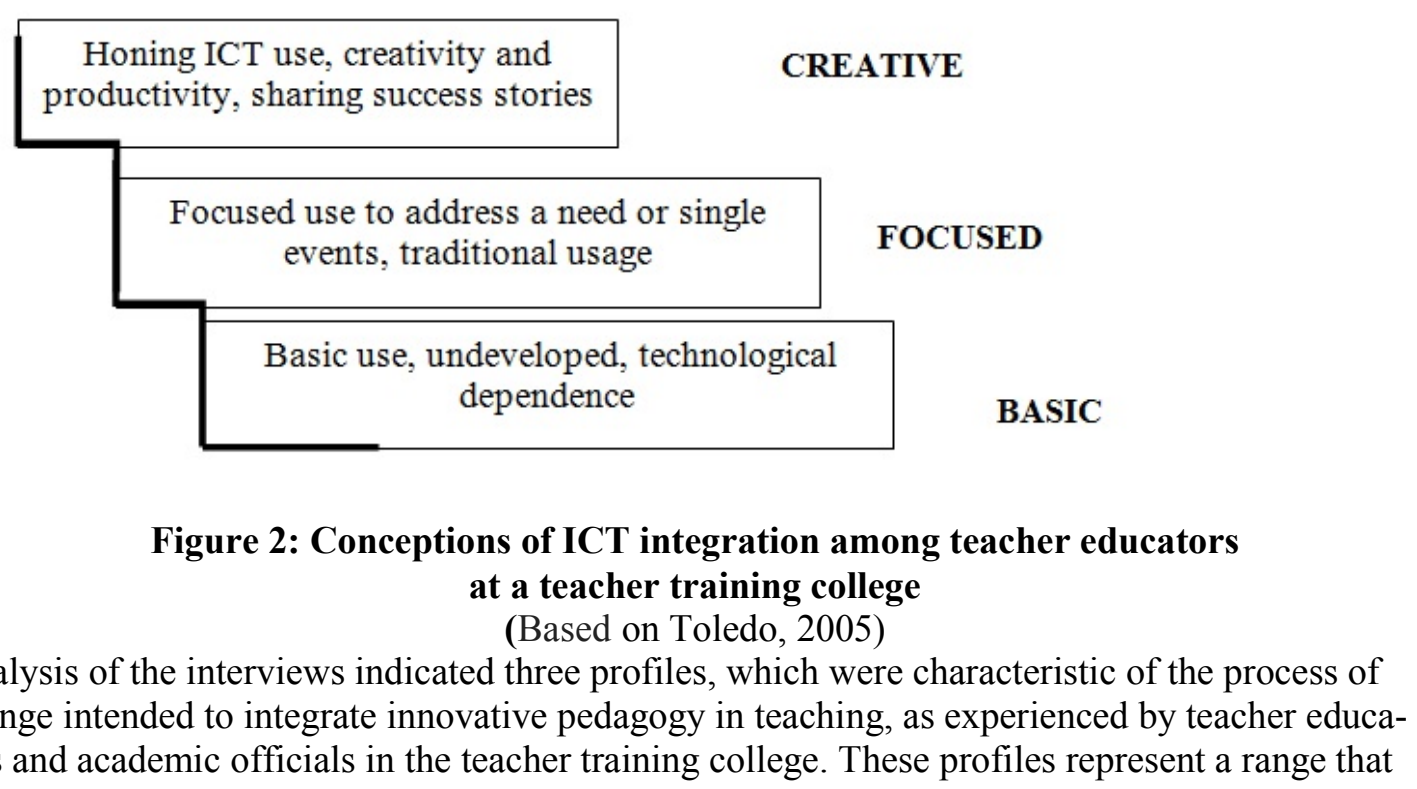


conveys a hierarchy of integration. An examination conducted in the framework of this study indicated that the three levels of ICT integration found among teacher educators also characterize the ICT-integration profile of the college on the whole: $9.6 \%$ of the teacher educators matched the basic-level profile, $35.6 \%$ of the teacher educators matched the focused-level profile, and $53.8 \%$ of the teacher educators fit the creative-level profile. The college profile of ICT integration is presented in Figure 3.

Percentage of teachers

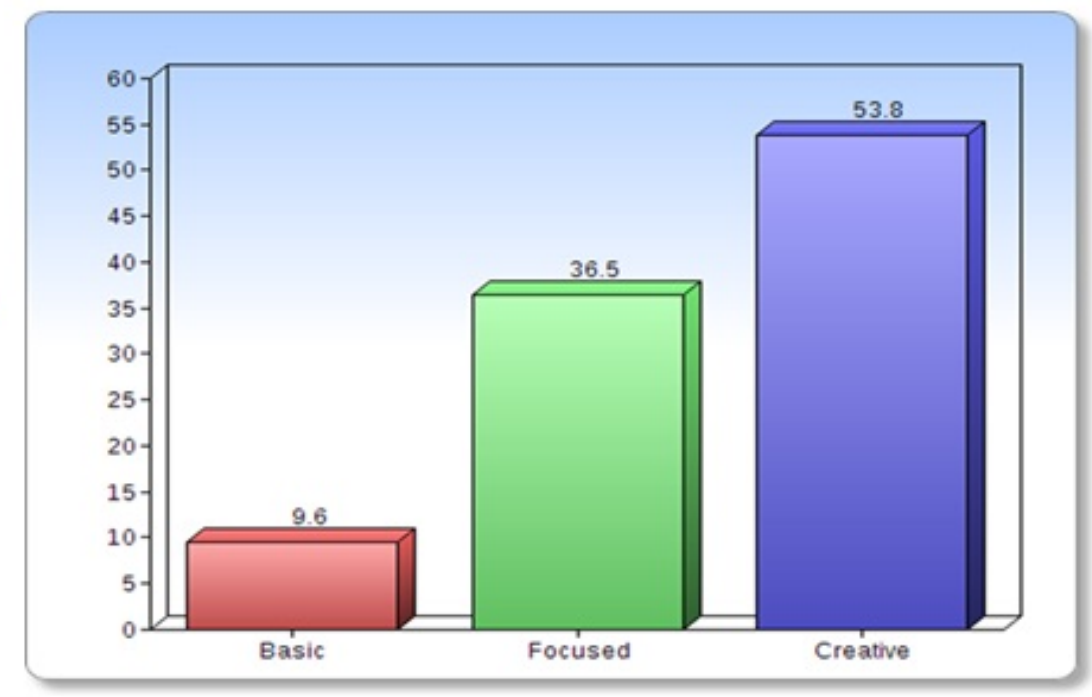

Figure 3: Integration of innovative pedagogy among teacher educators in a teacher training college

The $\mathrm{X}$-axis presents the three levels of implementation (basic, focused, and creative) and the $\mathrm{Y}$ axis represent the percentages of teachers at each level. The vertical line shows the percentage of teacher educators at each implementation level, while the horizontal line is descriptive to demonstrate the increase of incidence as the X-axis progresses towards the creative level of implementation. The three levels, based on Toledo's model (Toledo, 2005), are described below.

\section{The basic level}

The basic level suggests the use of simple and basic technologies (e.g., presentations or uploading the syllabus to the course site) and to a large extent technological dependence, which necessitates constant accompaniment and support. Teacher educators that fit this profile generally lacked technological know-how, which made it difficult for them to combine technological, pedagogical, and content knowledge in an informed manner. This difficulty can lead to anxiety, related to the use of technological tools. The following example is an excerpt from one of the interviews:

"There are those who make do with only a computerized presentation and that's all. In the last semester I didn't find anyone who didn't know how to upload the syllabus to the course site. They do that and also upload presentations to the website prior to the lesson. That is to say, the minimum has already been achieved. "(Iris, Masters in Education track).

\section{The focused level}

At this level, teacher educators use ICT in their teaching in a focused manner, to meet their ongoing immediate needs, as they apply the use of ICT to discrete instances and events, entailing 
short-term usage. Typically ICT use at this level is traditional. The following excerpt serves as an example:

"You expect lecturers to know the material; if they teach literature, you expect them to know about literature. Thus, if they teach you ICT, you expect them to know how to use ICT in general, not only the part that was prepared for this particular lesson." (Rotem, Elementary School Education track).

\section{The creative level}

The creative level is characterized by cooperation, creativity, and the production of innovative pedagogy in the lessons delivered by the teacher educators. Teacher educators who fit this profile demonstrate openness, conceptual flexibility, and motivation to share their success stories, both in the organization and beyond.

"For the one-day seminar that was held, I took the six skills defined by the Ministry of Education in its ICT program and demonstrated how they are integrated in the virtual courses I teach. This lecture received a lot of attention from the team members here at the college, as well as from professionals from outside the college." (Hila, Special Education track).

To examine whether differences in teacher educators' level of technological-pedagogical knowledge were related to their ICT integration level (basic, focused, or creative), a one-way ANOVA was conducted. Thus, differences between the levels of ICT integration were considered in terms of TPACK-related knowledge. The result of this analysis was statistically significant $\left[\mathrm{F}(2,49)=11.93, \mathrm{p}<.001, \mathrm{ETA}^{2}=.33\right]$. To examine the source of differences between the groups, a Tukey analysis was conducted. The result of this analysis indicated that teacher educators whose ICT integration fit the creative profile $(\mathrm{M}=4.49, \mathrm{SD}=.11)$ and those whose ICT integration fit the focused profile $(\mathrm{M}=4.08, \mathrm{SD}=.14)$ reported a level of technological-pedagogical knowledge that was significantly higher than that of teacher educators at the basic ICT integration level $(M=3.12$, $\mathrm{SD}=.27$ ), as described in Figure 4.

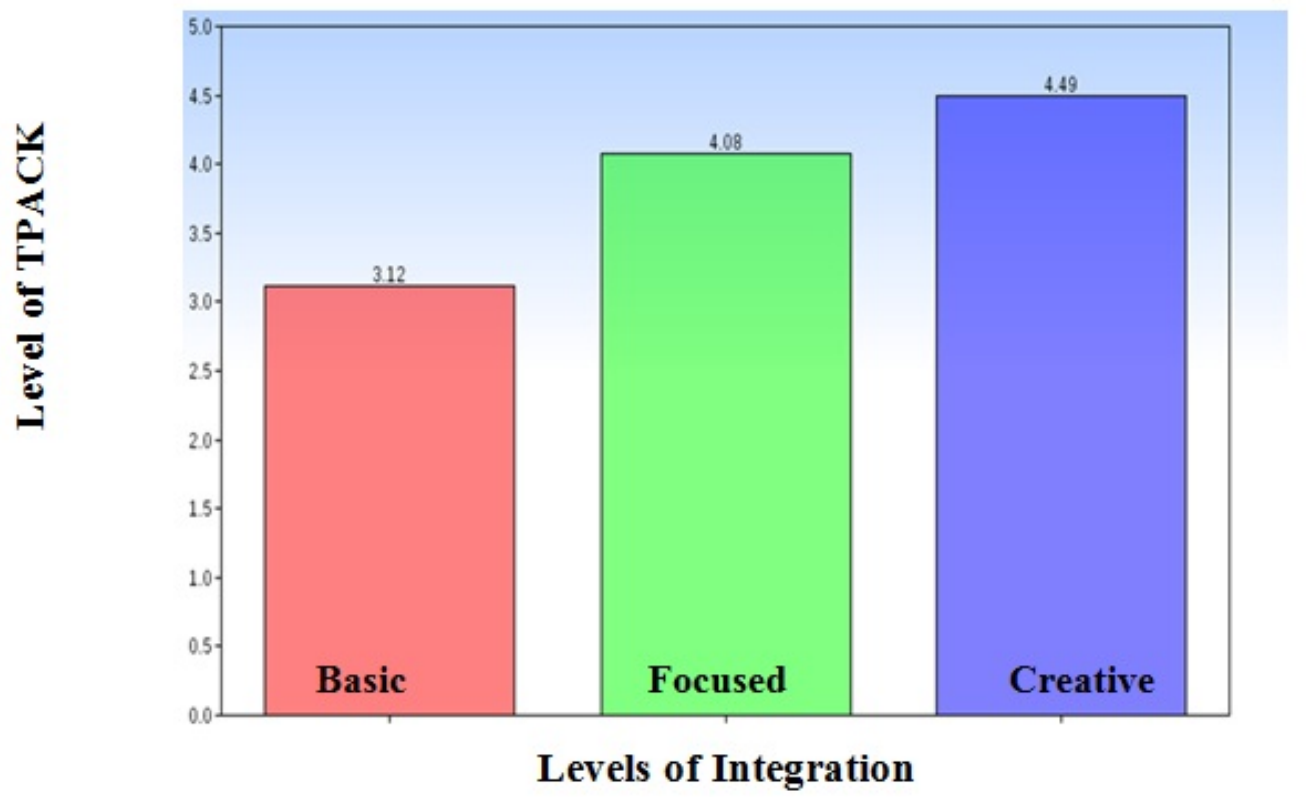

Figure 4: The differences in the level of TPACK of teacher educators as a function of the levels of integration 
Figure 4 shows the differences in the level of technological-pedagogical knowledge of teacher educators as a function of the level of integration where they are positioned (creative, focused, basic). The $\mathrm{X}$-axis is the level of integration and the $\mathrm{Y}$-axis is the level of technologicalpedagogical knowledge of teacher educators.

To examine whether differences in the attitudes of teacher educators to ICT integration were a function of their ICT-integration level (basic, focused, or creative), a one-way ANOVA was conducted. The result of this analysis was statistically significant $\left[\mathrm{F}(2,49)=6.77, \mathrm{p}<.01, \mathrm{ETA}^{2}=.21\right]$. To detect the source of the differences between these groups, a Tukey analysis was conducted. Results indicated a statistically significant difference $\left[\mathrm{F}(2,49)=6.77, \mathrm{p}<.01, \mathrm{ETA}^{2}=.21\right]$ between the $53.8 \%$ of teacher educators at the creative level $(\mathrm{M}=4.39, \mathrm{SD}=.11)$, the $36.5 \%$ of teacher educators at the focused level $(\mathrm{M}=3.94, \mathrm{SD}=.14)$, and the 9.6 teacher educators at the basic level $(\mathrm{M}=3.43, \mathrm{SD}=.27)$, as shown in Figure 5.

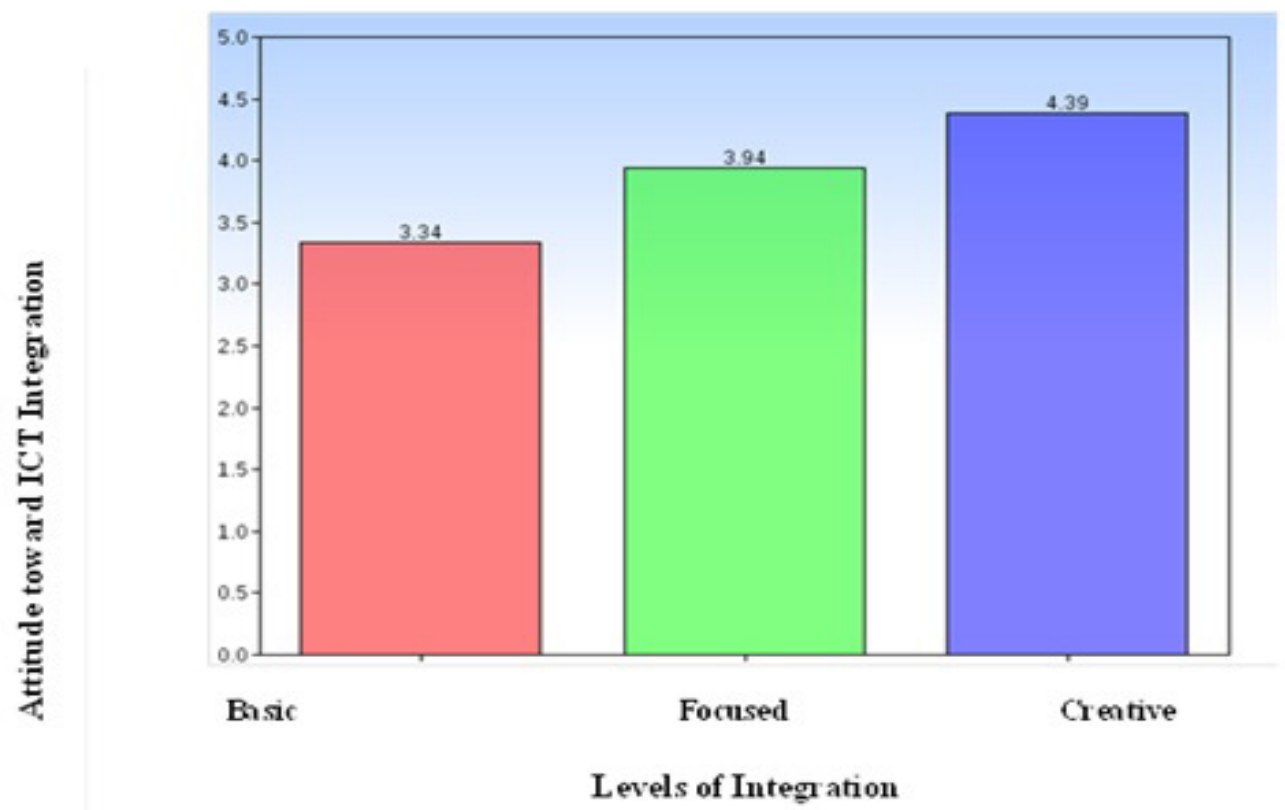

Figure 5: Attitude toward ICT integration as a function of level of integration

Thus, it appears that teacher educators whose ICT integration style corresponds to the focused level find it difficult to move to a higher level, despite their high-level technological-pedagogical skills. This difficulty appears to be due to their attitudes towards ICT integration and pedagogical innovation in teaching. The attitude factor can serve to either encourage or inhibit progress in the level of ICT integration (N. Davis \& Thompson, 2005).

The methodology permitted a triangulation of data collected using various tools and from different sources, rendering a broad and clear picture of the phenomenon under study and enabling an in-depth understanding of the process of integrating innovative pedagogy. At the same time, it provided an overview of the implementation of the program for Adapting Teacher Training Colleges to 21st Century Education, in the context of a teacher training college in its first year of the integration program. 


\section{Discussion of Results and Model}

Analysis of the quantitative and qualitative findings presents a picture that maps teacher educators' ICT integration levels and their location on the ICT integration continuum, in a teacher training college in its first year of implementing the program for "Adapting Teacher Training Colleges to 21st Century Teaching". The findings establish an initial infrastructure for formulating a model that addresses the research questions. The model describes the process of integrating innovative pedagogy into the teaching practices of teacher educators and academic officials in a teacher training college and provides a framework for understanding the optimal integration style. This model is presented in Figure 6.

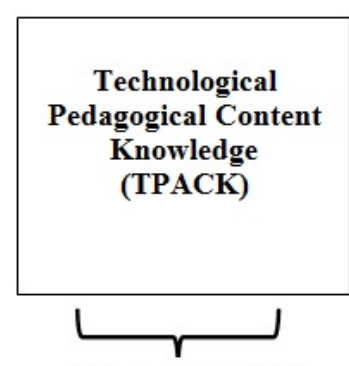

(1) personal skills

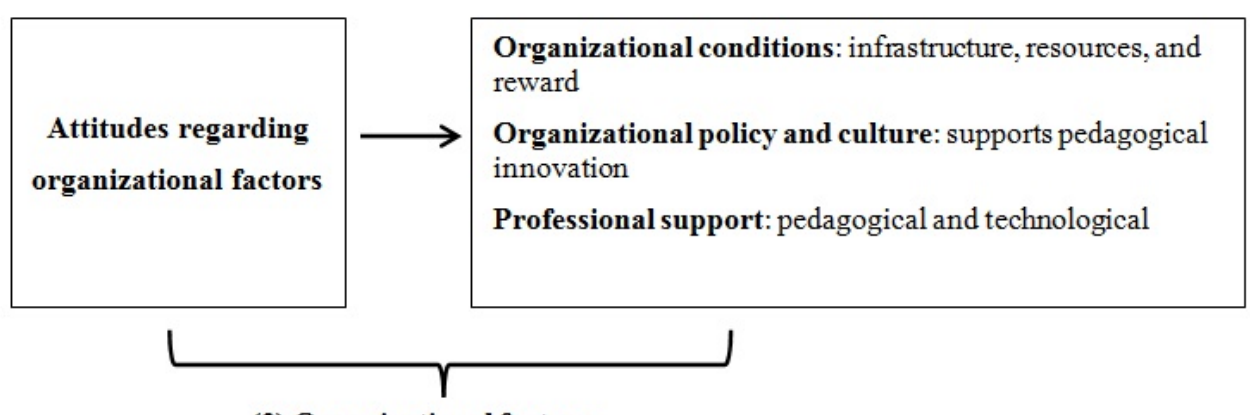

(3) Organizational factors
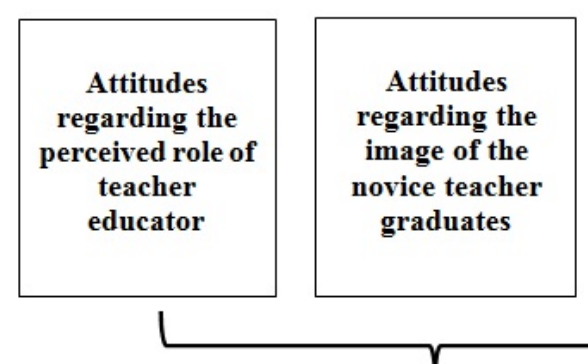

(2) Personal factors

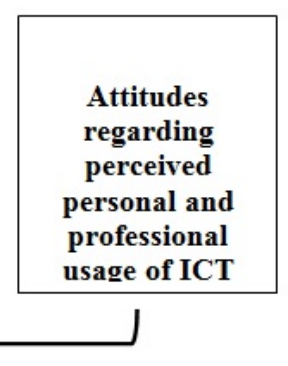

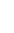


tive pedagogy is integrated by teacher educators and academic officials in a teacher training college. The different levels create a continuum that reflects the optimal type of integration and its characteristics. The characteristics of each of the different levels reflect different ICT-integration profiles of teacher educators and academic officials, as they engage in integrating innovative pedagogy in their teaching.

The basic level on the continuum is equivalent to the entrance stage in the five-stage model of ACOT (Sandholtz et al., 1997). This stage involves initial experimentation with the new technology, which is accompanied by a sense of discomfort; the teacher avoids using technologies for teaching purposes and continues to use traditional teaching methods, while using the difficulties as a rationalization for technology avoidance. The focused level parallels the stage of adoption in the five-stage ACOT model (Sandholtz et al., 1997; Toledo, 2005). At this stage, teachers understand the need for change, a change which includes integrating technology in teaching. However, no substantial change is introduced into their teaching style. The integration of ICT in teaching is used as a mechanism that is used to support traditional teaching methods. At the creative level, teacher educators demonstrate behaviors that parallel the highest stage in the five-stage ACOT model. The creative stage is characterized by teachers' in-depth understanding of the importance of using technology, and they are motivated to apply and use ICT. The technology, at this stage, constitutes a means through which teachers create and design innovative learning environments. These teachers can be described using the term suggested by Mishra \& Koehler (2006): "digitally wise teachers". These teachers have the capacity for technological independence, as they can acquire technological-pedagogical knowledge, based on their practical experience in operating ICT. This model also parallels that of Hall and Hord (1987), which they termed "interest-based adoption". Furthermore this study indicates that exposure to and acquisition of knowledge alone is not sufficient for effective ICT integration or for creating a substantial change in teaching; rather, for a significant change to take place, the beliefs and perceptions of the personal are the factors that affect personal behaviors and the manner in which innovative pedagogies are integrated in teaching (N. Davis \& Thompson, 2005; Ertmer \& Ottenbreit-Leftwich, 2010).

Thus, it appears that those teacher educators who are at the creative level constitute only an "island of innovation" (Avidov-Ungar, 2010) within the teacher training college, a type of "success story", which does not easily infiltrate or affect the entire organization (Avidov-Ungar. \& EshetAlkakay, 2011). Hence, once a critical mass from among the organization's members adopts and internalizes the change, as an essential part of their conceptualization of teacher training, only then will an essential change occur, the kind of change that lasts over the long-term (Nichols, 2008). Studies that examined the beliefs and skills of teachers who integrate ICT in schools found that their beliefs and skills act as major factors that affect the efficacy of the integration (Borko, 2004).

\section{Conclusion}

This study attempted to identify the skills and attitudes of teacher educators and college officials regarding teacher training to integrate ICT in teaching, and to examine the levels of implementation of innovative ICT pedagogy in teacher educators and officials at a teacher training college. The findings indicate that there are three major integration levels: basic, focused, and creative. The study highlights that teacher educators have the potential to move and progress to a high level provided they have technological and pedagogical skills and have positive attitudes about ICT and its assimilation in the school system. These are the requirements for moving from the basic to the creative level of implementation of innovative ICT.

Thus, it may be concluded that the uniqueness of the presented model is in depicting a continuum of levels of ICT integration and in revealing the factors necessary for effective integration. The current study focuses on a single college at a particular point in the integration process; neverthe- 
less, its findings provide a novel conceptualization of the relationship between influential factors and the hierarchy of ICT integration levels that exists among teacher educators in teacher training colleges.

The teacher educators are a role model for the students training to become teachers, thus it is important to evaluate the level of ICT implementation within the college courses. The model presented in the study embraces the key factors that influence ICT level of implementation on the personal factors and the organizational factors. Thus, it can assist decision makers in the field of professional development in constructing ways to lead teacher educators from the basic level to the creative level of implementation. Also, it is of value to evaluate the level of ICT use among teacher educators on the different levels of implementation.

Future studies might examine the model in additional teacher training colleges at different points in the ICT integration process. Furthermore, there is reason to expect that the model may be applicable to the ICT integration process in K-12 schools.

\section{References}

ASTC (2010). Assessment \& Teaching of 21st Century Skills. Retrieved March 30, 2014 from: http://atc21s.org/wp-content/uploads/2011/04/January2010StatusReport.pdf

Avidov-Ungar, O. (2010). "Islands of innovation" or "comprehensive innovation" assimilating educational technology in teaching, learning, and management: A case study of school networks in Israel. Interdisciplinary Journal of E-Learning and Learning Objects, 6, 259-280. Retrieved from http://www.ijello.org/Volume6/IJELLOv6p259-280Avidov704.pdf

Avidov-Ungar, O. \& Eshet-Alkakay, Y. (2011). The islands of innovation model: Opportunities and threats for effective implementation of technological innovation in the education system. Issues in Informing Science and Information Technology, 8, 363-376. Retrieved from http://iisit.org/Vol8/IISITv8p363376Avidov213.pdf

Back, S. (2012). Ways of learning to teach. A philosophically inspired analysis of teacher education programs. Rotterdam: Sense publishers.

Barak, M., Ben-Chaim, D., \& Zoller, U. (2007). Purposely teaching for the promotion of higher-order thinking skills: A case of critical thinking. Research in Science Education, 37(4), 353-369.

Barak, M., Carson, K. M., \& Zoller, U. (2007). The "chemistry is in the news" project: Can a workshop induce a pedagogical change? Journal of Chemical Education, 84(10), 1712-1716.

Barell, J., Darling-Hammond, L., Dede, D., DuFour, R, DuFour, R., Fisher, D., Fogarty, R.G., Frey, N., Gardner, H., Hargreaves, A., Johnson, D.W., Johnson, R.T., Lemke, L., McTighe, J., November, A., Pearlman, B., Pete, B.M., Reeves, D., Richardson, W., Seif, E. (2010). 21st Century Skills: Rethinking How Students Learn (Ed. by Bellanca, J. \& Brandt, R.). Learning Edge series.

Beaudin, L., \& Hadden, C. (2005). Technology and pedagogy: Building techno-pedagogical skills in preservice teachers. Innovate, 2(2). Retrieved May 9, 2014 from:http://citeseerx.ist.psu.edu/viewdoc/download?doi=10.1.1.115.8647\&rep=rep1\&type=pdf

Birch, D., \& Sankey, M. D. (2008). Drivers for and obstacles to the development of interactive multimodal technology-mediated distance higher education courses. International Journal of Education and Development Using ICT,4(1). Retrieved April 1, 2011 from http://ijedict.dec.uwi.edu/viewarticle.php?id=375\&layout $=\mathrm{html}$

Black, G., \& Smith, K. (2009). Hot topic: ICT in pre-service teacher training strategic ICT advisory service, Australian Government's Department of Education, Employment and Workplace Relations. Retrieved March 31, 2014 from http://dspace.edna.edu.au/dspace/bitstream/2150/54714/1/SICTAS_HT_pre-service.pdf 
Borko, H. (2004). Professional development and teacher learning: Mapping the terrain. Educational Researcher Journal, 33(8), 3-15.

Bransford, J. D., Brown, A. L., \& Cocking, R. R. (2000). How people learn: Brain, mind, experience, and school (Expanded ed.). Washington, D.C.: The National Academies.

Bransford, J. D., Darling-Hammond, L., \& LaPage, P. (2005). Introduction. In L. Darling-Hammond \& J. Bransford (Eds.), Preparing teachers for a changing world: What teachers should learn and be able to do (pp. 358-389). San Francisco: Jossey-Bass.

Brzycki, D., \& Dudt, K. (2005). Overcoming barriers to technology use in teacher preparation programs. Journal of Technology and Teacher Education, 13(4), 619-641.

Bullock, D. (2004). Moving from theory to practice: An examination of the factors that preservice teachers encounter as the attempt to gain experience teaching with technology during field placement experiences. Journal of Technology and Teacher Education, 12(2), 211-237.

Cochran-Smith, M. (2005). Teacher educators as researchers: Multiple perspectives. Teaching and Teacher Education, 21, 219-225.

Collier, S., Weinburgh, M. H., \& Rivera, M. (2004). Infusing technology skills into a teacher education program: Change in students' knowledge about and use of technology. Journal of Technology and Teacher Education, 12(3), 447-468.

Darling-Hammond, L. (2000). Teacher quality and student achievement. Educational Policy Analysis Archive, 8(1), 1-44.

Davis, F., Bagozzi, R., \& Warshaw, P. (1989). User acceptance of computer technology: A comparison of two theoretical models. Management Science, 35(8), 982-1003.

Davis, N., \& Thompson, A. (2005). The evaluation of technology-related professional development, Part 2. In C. Crawford et al. (Eds.), Proceedings of Society for Information Technology and Teacher Education International Conference 2005 (pp. 825-830). Chesapeake, VA: AACE.

Dawson, K. (2006). Teacher inquiry: A vehicle to merge prospective teachers' experience and reflection during curriculum-based, technology-enhanced field experiences. Journal of Research on Technology in Education, 38(3), 265-292.

Ertmer, P. A., \& Ottenbreit-Leftwich, A. T. (2010). Teacher technology change: How knowledge, confidence, beliefs, and culture intersect. Journal of Research on Technology in Education, 42(3), 255-284.

Fullan, M. (2001). The new meaning of educational change (3rd ed.). New York: Teachers College Press. I

Fullan, M. (2013). The new pedagogy: Students and teachers as learning partners. Accessed Feb. 4, 2014 from http://www.learninglandscapes.ca/images/documents/ll-no12/fullan.pdf

Goktas, Y., Yildirim, S., \& Yildirim, Z. (2009). Main barriers and possible enablers of ICTs integration into pre-service teacher education Programs. Educational Technology \& Society, 12(1), 193-204.

Goldstein, O., Avidov Ungar, O., Asaf, M., Barak, M., Ganayem, A., Waldman, N., Forkush-Baruch, A., Peled, R., Peled, Y.,Ramati, D., \& Shonfeld, M. (2012). Adapting Teacher Training Colleges to 21st Century Education: Planning, implementation, and evaluation - A research proposal. Mofet Institute, Israel.

Gomez, L. M., Sherin, M. G., Griesdorn, J., \& Finn, L. (2008). Creating social relationships: The role of technology in preservice teacher preparation. Journal of Teacher Education, 59(2), 117-131.

Granston, N. C. (2004). Technology and teacher training: The systematic design and development of a framework for integrating technology into Jamaica's teacher training programs. A dissertation submitted in partial fulfillment of the requirements for the degree of Doctor of Philosophy. Department of Secondary Education. College of Education. University of South Florida.

Gronseth, S., Brush, T., Ottenbreit-Leftwich, A., Stryker, J., Abaci, S., Easterling, W., \& van Leusen, P. (2010). Equipping the next generation ofteachers: Technology preparation and practice. Journal of 
Digital Learning in Teacher Education, 27(1), 20-26. Retrieved March 31, 2014 from http://mypage.iu.edu/ sgronset/2010-JDLTE-27-1-030.pdf

Hall, G. E., \& Hord, S. M. (1987). Change in schools: Facilitating the process. Albany, NY: SUNY Press.

Harris, J., \& Hofer, M. (2009). Instructional planning activity types as vehicles for curriculum-based TPACK development. In C. D. Maddux. (Ed.), Research highlights in technology and teacher education (pp. 99-108). Chesapeake, VA: Society for Information Technology.

ISTE [International Society for Technology in Education] (2008). National educational technology standards. Retrieved April 2, 2014 from http://www.iste.org/standards/standards-for-teachers/nets-forteachers-2008

Kay, R. H. (2006). Evaluating strategies used to incorporate technology into preservice education: A review of the literature. Journal of Research on Technology in Education, 38(4), 383-408.

Maltz, L., \& DeBlois, P. B. (2005). Current IT issues. EDUCAUSE Review, 40(3), 14-29.

McKinsey Report. (2007). How the world's best-performing school systems come out on top. Retrieved April 2, 2014, from http://www.teacherqualitytoolbox.eu/news/4/mckinsey_report_how the_world_s best_performing sc hool_systems_come_out_on_top

Ministry of Education, Administration of Training and Professional Development of Teaching Personnel, Department of Training for Teaching Personnel. (2011). Adapting Teacher Training Colleges to 21st Century Education. Retrieved April $2^{\text {nd }}, 2014$, from http://cms.education.gov.il/educationcms/units/madatech/ictineducation

Mishra, P., \& Kereluik, K. (2011). What 21st Century Learning? A review and a synthesis. In Proceedings of Society for Information Technology \& Teacher Education International Conference 2011 (pp. 127129). Chesapeake, VA: AACE.

Mishra, P., \& Koehler, M. J. (2006). Technological pedagogical content knowledge: A new framework for teacher knowledge. Teachers College Record, 108(6), 1017-1054.

Moser, Z. F. (2007). Faculty adoption of educational technology. Educause Quarterly,30(1), 66-69. Retrieved April 1, 2014 from http://www.alexandria.unisg.ch/publications/34660.

National Research Council. (1996). Nutrient requirements of beef cattle (7th ed.). Washington, DC: National Academy Press.

Nichols, M. (2008). Institutional perspectives: The challenges of e-learning diffusion. British Journal of Educational Technology, 39(4), 598-609.

OECD [Organisation for Economic Co-operation and Development]. (2010). Inspired by technology, driven by pedagogy: A systemic approach to technology-based school innovations. Retrieved April 2, 2014, from http://www.oecdbookshop.org/oecd/display.asp?sf1=identifiers\&st1=9789264094789

Partnership for 21st Century Skills (P21). (2009). The partnership for 21st century skills. Retrieved March 30, 2014 from http://www.p21.org

Postholm, M. B. (2006). The teacher's role when pupils work on task using ICT in project work. Educational Research, 48(2), 155-175.

Salomon, G. (1992). The changing role of the teacher: From information transmitter to orchestrator of learning. In F. K. Oser, A. Dick, \& J. Patry (Eds.), Effective and responsible teaching the new synthesis (pp. 35-49). San Francisco: Jossey-Bass Publishers.

Sandholtz, J. H., Ringstaff, C., \& Dwyer, D.C. (1997). Teaching with technology: Creating student centered classrooms. New York: Teachers College Press.

Sharples, M., McAndrew, P., Weller, M., Ferguson, R., FitzGerald, E., Hirst, T., \& Gaved, M. (2013). Innovating Pedagogy 2013: Open University Innovation Report 2. Milton Keynes: The Open University. Accessed Feb. 4, 2014 from 
http://www.open.ac.uk/personalpages/mike.sharples/Reports/Innovating_Pedagogy_report_2013.pdf Toronto: Pearson.

Siemens, G., \& Tittenberger, P. (2009). Handbook of emerging technologies for learning. Retrieved April 2, 2014 from http://elearnspace.org/Articles/HETL.pdf

Strauss, A., \& Corbin, J. (1990). Basics of qualitative research: Grounded theory procedures and technques. London: Sage Publications.

Surry, D., Ensminger, D., \& Jones, M. (2003). A model for integrating instructional technology into higher education. Retrieved April 1, 2014 from: http://iphase.org/papers/RIPPLES.rtf

Swennen, A., \& van der Klink, M. (2009). Becoming a teacher educator: Theory and practice for teacher educators. Heidelberg: Springer.

Toledo, C. (2005). A five-stage model of computer technology integration into teacher education curriculum. Contemporary Issues in Technology and Teacher Education, 5(2), 177-191.

Valdez, G., Fulton, K., Glenn, A., Wimmer, N., \& Blomeyer, R. (2004). Effective technology integration in teacher education: A comparative study of six programs. Innovate, 1(1). Retrieved April 1, 2014 from http://www.innovateonline.info/index.php?view=article\&id=4.

\section{Appendix}

\section{Teacher educators integrated ICT - Semi-structured Interview}

The interview forms part of an intercollegiate evaluation being undertaken by a group of researchers in the Mofet institute, studying ICT integration in teacher education colleges. It includes questions about their vision concerning the National Program for transforming the educational system to meet the demands of the 21 st century, its main ideas, strategies and ways of implementation.

These questions are for interviewing department managers, heads of faculties and heads of programs.

\section{Personal Standpoint}

1. What do you think about ICT and its integration into teaching?

2. How do you use ICT for your own personal use?

3. Do you enjoy working on the computer?

\section{College Vision}

4. Was this idea mentioned in the vision of your college?

5. Does the management support integration of ICT in teaching?

\section{Information on the Extent of the Integration of ICT in a Course of Study}

6. How many teachers are on a course?

7. How many of them use ICT? In what ways?

\section{Teacher Training in a Specific Department/Program}

8. Did any activities take place so as to insure ICT assimilation in the course? Through inservice teams or workshops? If so, how were the teachers influenced by this activity / these activities?

9. Were there any team member presentations of their experience in ICT or of their research on ICT? How were the other teachers influenced by these presentations? 
10. In your opinion, how should ICT be assimilated into the team teachers' teaching?

11. Do you use ICT in your teaching? If so, how?

\section{Educational and Pedagogical Innovation}

12. Are there any teachers that employ ICT for unusual tasks?

\section{Support and Difficulties}

13. What are the major difficulties that teachers have in using ICT? What encourages and what discourages teachers from using ICT?

14. Is technical and pedagogical support enough? Who provides this support?

\section{Training Students for ICT in Teaching}

15. How are the students prepared for ICT? What kind of courses are there?

16. Is there a mandatory course in ICT?

17. Are students required to teach using ICT while they are in their first year of student teaching?

18. Do students choose ICT as their final project?

19. In your opinion, to what extent are students ready / able to teach via ICT?

20. How does the new curriculum influence the student syllabus pertaining to training teachers for ICT?

\section{Awareness of the Situation in Schools}

21. Do you know of the integration of ICT in schools? From which source?

22. How will ICT influence the future of schools?

\section{Recommendations for Policy Setters in Colleges and the Ministry of Education}

23. In your opinion, how does the new college curriculum influence ICT assimilation in the college?

24. What is the recommended way to assimilate ICT?

25. Which metaphor comes to mind when you think of ICT?

\section{Biographies}

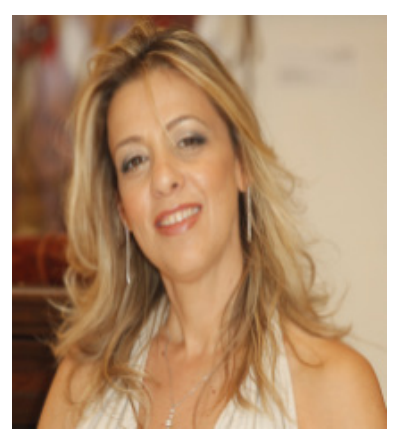

Dr. Orit Avidov-Ungar is the Head of Research Authority and senior lecturer at the School of Education Systems Management at Achva Academic College. She is also a member of the faculty of the Open University of Israel.

She heads the team specializing in professional development at the Mofet Institute and is academic advisor to the Ministry of Education in Israel on management of the implementation of innovative technology systems and the professional development of teachers. Her research studies deal with the implementation of innovative technologies in education systems, the empowerment and professional development of teachers, and leading organizational change in education systems. 


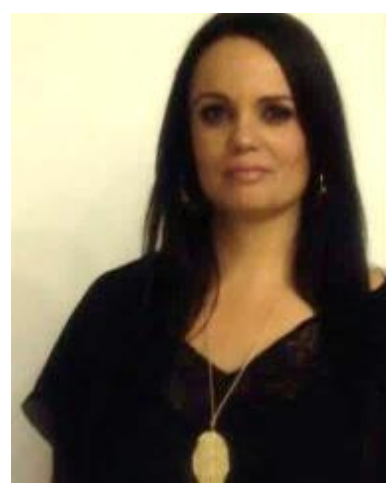

Irit Emma Iluz is a special education teacher and didactic diagnosis expert in the "Be'eri" experimental school in Beer Sheva.

She is the school's integration coordinator, member of the evaluation team and experiential group of the school. She has a B.A. in special education from Kaye College and an M.Ed. in Educational Systems Management from Achva Academic College. Her research project dealt with assimilation of innovative pedagogy in training for teaching. 